\title{
The Effects of Organizational Politics on Perceived Organizational Justice and Intention to Leave
}

\author{
Nihat Kaya', Samet Aydin'2, Ozgur Ayhan ${ }^{3}$ \\ ${ }^{1}$ School of Business, Gebze Technical University, Kocaeli, Turkey \\ ${ }^{2}$ Graduate School of Social Sciences, Maltepe University, Istanbul, Turkey \\ ${ }^{3}$ Defense Sciences Institute, Turkish Military Academy, Ankara, Turkey \\ Email: sametaydin@hotmail.com
}

Received 17 February 2016; accepted 14 March 2016; published 17 March 2016

Copyright (C) 2016 by authors and Scientific Research Publishing Inc.

This work is licensed under the Creative Commons Attribution International License (CC BY). http://creativecommons.org/licenses/by/4.0/

(c) (i) Open Access

\begin{abstract}
The purpose of this study is to examine the perceptions about organizational politics held by members of different organizations and how these affect their perceptions of organizational justice and decisions relating to employee turnover. For this study, 259 completed surveys were obtained from various public and private sector personnel. After the measures used in the study were verified through confirmatory factor analysis, correlation and regression analyses were then conducted in order to determine the relationship between variables. As a result of the study, it was found out that organizational politics had a significant effect on perceived organizational justice and intention to leave. In addition to those results, a significant relationship was further found between perceived organizational justice and intention to leave.
\end{abstract}

\section{Keywords}

Organizational Politics, Perceived Organizational Justice, Intention to Leave

\section{Introduction}

Organizations should try to derive maximum benefit from their human resources in order to maintain a sustainable competitive advantage and constantly increase their efficiency and productivity. Conversely, organizations that are incapable of realizing the value of their human resources will find competition harder. While there are disadvantages relating to competition, the benefits are also indispensably true. Although organizations give due importance to human resources at the macro level, it can be observed that individuals create competition be- 
tween others in order to increase their personal benefits and gains. The phenomenon of organizational politics has emerged through the presence of these processes.

Politics, which is concerned with attempting to secure and develop individual benefits [1] [2], can in fact be accepted as an output of competition. In the family, which is the smallest organization found in the community, politics is simply discussed; in much larger organizations, more significant political encounters should not be surprising [3]. Individuals utilize politics as a tool that is necessary for competition. Therefore, thanks to this tool, they are able to obtain power over their competitors. Although individuals increase their benefits through politics, the perception of justice is seen as the most important aspect in an organization that is politically structured.

Organizations try to maintain justice internally by establishing rules and following legislation. If organizational politics and organizational justice are handled together, it may be observed that, by establishing justice, output distribution is conducted in such a way that each individual gets as much as they deserve. Conversely, individuals try to cultivate their individual benefits with politics. Previous studies in organization management emphasized the effects of organizational politics on employees' work outcomes such as job satisfaction, job related stress [4], trust in company, and organizational commitment [5] [6]. One of the most important negative consequences of the oppositional relationship between politics and justice is the increase in employee turnover [7]-[9]. Many employees do not want to work in an unfair working environment in the long-term, in which a range of political behaviours is experienced. As a result of such situations, they foster a desire to leave or form a negative attitude towards the organization [10]-[12]. In contrast, some scholars indicated that organizational politics may also have positive effects if the behaviours are in line with organizational targets [13] [14].

Organizational justice is also reported to have impacts on turnover and job satisfaction [15] [16]. [17] stated that perceptions about organizational justice make positive impacts on employees' work outcomes. Some scholars emphasized the relation between organizational politics and organizational justice [10] [17]-[19]. [20] stated that when organizational justice perceptions are high then the relation of organizational politics and turnover intention becomes weak.

The purpose of this study is to understand how perceptions about organizational politics by individuals impact upon perceived organizational justice and intention to leave. As [7] stated, employees who decide to leave their current job may not give enough attention to their current responsibilities. In order to address this purpose, this study was conducted with various public and private sector personnel in Turkey. In addition to the effects upon employees' perceptions about organizational justice and intention to leave, the impact of organizational justice upon employee turnover was also analyzed.

\section{Literature Review}

\subsection{Organizational Politics}

Politics involves a set of influencing behaviours that are displayed in order to secure and develop individual or group benefits [1]. The politics that is experienced within an organization is a basic reality of life [21]. Firstly, political presence or perception within an organization should be defined in order to understand and manage this real life phenomenon in a better way. [3] claimed that each organization is a political structure. Additionally, gaining power and attempting to influence colleagues using gained power in various ways and means create organizational politics [22].

Reference [23] defined organizational politics as the use of power in order to obtain results that are either not approved by the organization or use tools that are also not approved by the organization. Although there are many different definitions of organizational politics, these definitions agree that organizational politics is a set of social-influencing processes, which are experienced within an organization in order to prevent short-or longterm individual benefits [5] [7] [14] [24] [25].

Organizational politics, which can be defined as converting the results of a specific situation to someone's benefit, such as influencing decision-making processes, can prevent or promote individual benefits. While this process sometimes takes place at an individual level, it can occur at a group level at other times, in which cooperation among individuals takes place in order to increase collective benefits [21]. [23] stated that organizational politics may be experienced at different levels in any organization, with the caveat that every behaviour ought not to be categorized as political within an organization. Meanwhile, [13] proposed that, if organizational politics is focused on securing and developing individual benefits, this will be in the overarching interests of the or- 
ganization.

The perception about organizational politics may vary from person to person within an organization [26] [27]. The perception of individuals about their working environment's political structure may affect how their thinking relates to their employers, managers and colleagues, as well as impact on their productivity levels, job satisfaction and intentions towards leaving the organization [21].

Perceived organization politics could be explored in five dimensions, listed as follows:

- Go Along to Get Ahead: This dimension explains the behaviours exhibited by employees in which they effectively stay silent. Some employees try to secure individual benefits without drawing attention to themselves. Employees may keep silent or show a passive attitude in order to prevent individual benefits in some circumstances [2].

- General Political Behaviours: This dimension focuses on how employees behave politically and the ways in which they derive individual benefits. [28], who stated that political behaviours tend to increase in an environment where rules and regulations are not followed, claimed that political behaviours can also be present in situations, such as a shortage of valuable resource.

- Pay and Promotion: This dimension explains the political behaviours in an organization's politics axis. [29] stated that this dimension explains why managers tend to prioritize those employees with whom they are closest and to whom they give higher averages during performance evaluation processes, so that these favoured employees enjoy better prospects of a salary increase and/or promotion. Moreover, employees may adopt certain political behaviours in order to encourage their managers to behave in the above-mentioned ways.

- Coworkers: This dimension tries to explain the political behaviours of both superiors and colleagues. Some personnel who are on the receiving end of negative behaviours may not able to respond effectively, and therefore may be the victim of these kinds of political behaviour [30].

- Self-serving Behaviours: This is one of the most important dimensions that can damage organizational efficiency. Self-serving is when individuals put their own interests above those of their colleagues and the organization as awhole [30].

Although it is a common situation that political behaviours are frequently experienced by members in many organizations, the causes and effects of such behaviours have still not been clearly identified and explained. The causes behind people displaying political behaviours could be as follows: (1) the presence of some groups who put their self-interest above others and before the aims of their organization; (2) some employees, who are excluded from and by such groups, think it is necessary to display such behaviours in order to get promoted; and, (3) the presence of bias towards salary and promotion decisions in organizations [27].

Reference [31] stated that political behaviours are more frequently experienced in higher level executive management positions, while perceptions about organizational politics held by employees in executive management are stronger than in lower ranks, since they have enough power to obtain and manage resources. That said, some studies have shown that political perceptions of lower level employees are also important [30]. The conclusion, then, is that the political perception of employees is affected by factors including centralization [32], span-of-control [21], job diversity, and existing promotion and development opportunities [30].

Reference [33] stated that, where organizational politics is highly perceived, then friendships in the working environment will be stronger. It is commonly accepted that employees are closer to each other when uncertainty is experienced at high levels, because employees are having difficulty in deciding which behaviours will be rewarded and which ones will be rejected [20] [34]. In some cases, securing individual benefits may in turn benefit everyone [14].

Besides, the negative outputs of organizational politics are more dominant [7]. Employees display three different types of behaviour when they regard their organizations as a political structure: (1) leaving the organization; (2) neither leaving the organization nor getting involved in the political structure; and (3) not leaving the organization and taking an active role in the political structure [21]. [35] Stated that, if the perception of organizational politics is high and employees' concerns about their jobs increase, their job satisfaction will decrease and the level of employee turnover will rise. For [5], perceived organizational politics affects commitment to the organization in negative ways. [7] stated that an environment, which is perceived as a political organization, will cause unfair situations that can be easily realized by employees. One of the most important negative characteristics of perceived organizational politics is about intentions to leave. [10] suggested that employees may be inclined to leave their organization, in both physical and psychological terms, if they regard it as a structure in which only the demands of strong members are accepted. In different studies, a correlation between perceived 
organizational politics and job uncertainty [36], job-related stress [4], organizational ambition [34] and intentions to leave [37] has been identified.

\subsection{Perceived Organizational Justice}

Justice perceived by individuals is very important in organizations in which social-based structures form a community. In the literature, it can be observed that the concept of organizational justice was first discussed by [38], and then by [39] and [40]. Moreover, [41] categorized the studies of justice conceptualization according to his own taxonomy, analyzing his classification in relation to two groups of dimensions: reactive and proactive dimensions, and process and content dimensions. Reactive justice theories focus on people's avoidance of and attempts to escape from perceived unfair situations, whereas proactive justice theories focus on attempts to improve justice conditions. The ways of determining outputs gain importance in the process dimension, while justice conditions are important when experienced during the distribution of outputs.

Organizational justice could be defined as a framework that is created through people's personal ideas about resources and methods of reward distribution, in which the distribution processes relate to the phenomena explained by the definitions and classifications of [41]. [42] Defined organizational justice as a perception about resources and reward distribution, distribution processes and interactions among people in organizations. Organizational justice is divided into three sub-dimensions: (1) distributive justice, (2) procedural justice and (3) interactional justice [42] [43].

Distributive justice emphasizes people's perceptions towards value and damage distribution [41] [42]. Procedural justice represents the level of justice perceived by employees during decision-making processes [43] [44]. Interactional justice focuses on the social aspects of the processes [43].

\subsection{Intention to Leave}

Reference [7] stated that employees who decide they wish to leave their current job may direct their energy to finding a new one, and in turn may not give enough attention to their current responsibilities. Therefore, the intention to leave may have as much impact as an employee actually leaving; this needs to be analyzed [45]. [46] defined the intention to leave a job in terms of an employee wishing to break away from their current organization. [47] accepted that the intention to leave is the most important indicator of why an employee genuinely wishes to leave.

The first type of job leaving situation is concerned with factors directly related to the job itself, such as working conditions, work schedule, payments and promotion opportunities over which the employer has complete control. [48] stated that there is another type, which is concerned with factors that are not directly related to job itself, but caused by an employee's personal life and how this affects their performance and attitude at work; as such, it is difficult for the employer to exercise much control in this regard. Another type of job leaving situation is derived from the incompatibility between an employee and their organization. [49] stated that one of the most interesting types of job leaving situation is "voluntarily-involuntarily job leaving". As the term suggests, it is a hybrid between voluntarily job leaving, in which an employee chooses to leave a job, and involuntarily job leaving, which is defined in terms of an employee who is forced to leave a job by their employer.

\section{Research Model}

The effects of perceived organizational politics over employee attitudes have been repeatedly researched and such studies show that these kinds of perception lead to job dissatisfaction as well as potential and actual employee turnover [12] [21] [45] [50].

Many employees do not want to work in an environment where many political behaviours are experienced. Therefore, the risk of employees leaving their job, if they perceive there is a high level of organizational politics, could be high [45]. Even if an employee is simply thinking about leaving, this could reflect underlying physical and psychological problems related to organizational politics [4]. The capacity of employees, who suffer from the political attitudes of highly self-interested colleagues, to cope with work-related stress could decrease to the point where they feel pressure to quit [50]. According to [10], an employee may be inclined to think about leaving their organization when they regard it as a structure in which only the demands of strong members are accepted. Additionally, an organization's members may want to leave their jobs if they see that organizational pol- 
itics exclude their friends.

Similar to each individual in the wider community, members in organizations wish to pursue their lives in an environment where justice can be maintained. Employees may leave an organization in cases where justice is lacking. [51] Stated that a lack of distribution and procedure justice can have important negative effects in relation to employee retention. [17], meanwhile, determined that employee perceptions of effective organizational justice can engender a positive impact on attitudes to work.

A strong correlation between perceived organizational justice and perceived organizational politics is therefore established [10]. In particular, employees will regard their working environment as unfair and biased where promotion is contingent on the politics within an organization, rather than on established rules and regulations, which in turn will feed the perception that organizational justice is dysfunctional [18]. [20] stated that an employee's political perceptions are low if their individual perceptions about justice within an organization are high. Moreover, [17] suggested that the perception of organizational justice will eliminate any negative effect of organizational politics.

Through these definitions, a research model is constructed, as shown in Figure 1.

$\mathrm{H}_{1}$ : There is a significantly positive relationship between organizational politics and intention to leave.

$\mathrm{H}_{2}$ : There is a significantly negative relationship between organizational politics and perceived organizational justice.

$\mathrm{H}_{3}$ : There is a significantly negative relationship between perceived organizational justice and intention to leave.

\section{Method}

Data for the study were collected by the survey method using five-point Likert scales. Organizational politics was measured using 24 items from [21]. Sample items were: "Employees are encouraged to speak out frankly even when they are critical of well-established ideas", "There is no place for yes-men around here; good ideas are desired even if it means disagreeing with superiors", and "Agreeing with powerful others is the best alternative in this organization". Perceived organizational justice was measured using [44] scale. Sample items were "My work schedule is fair", "Job decisions are made by my supervisor in unbiased manner", and "When decisions are made about my job, the supervisor treats me with kindness and consideration". Intention to leave was measured using a scale developed by [52] based on [46]'s study. The scale consists of three items including: "I intend to quit my present job", "I often think about quitting" and "I am actively searching for an alternative to my present job”.

The convenience sampling method was used, with a total of 259 employees from five public and four private companies participating in the study. The demographic characteristics are presented in Table 1. In order to confirm the validity and reliability of the scales, confirmatory factor analysis was conducted. The hypotheses were tested using regression analysis.

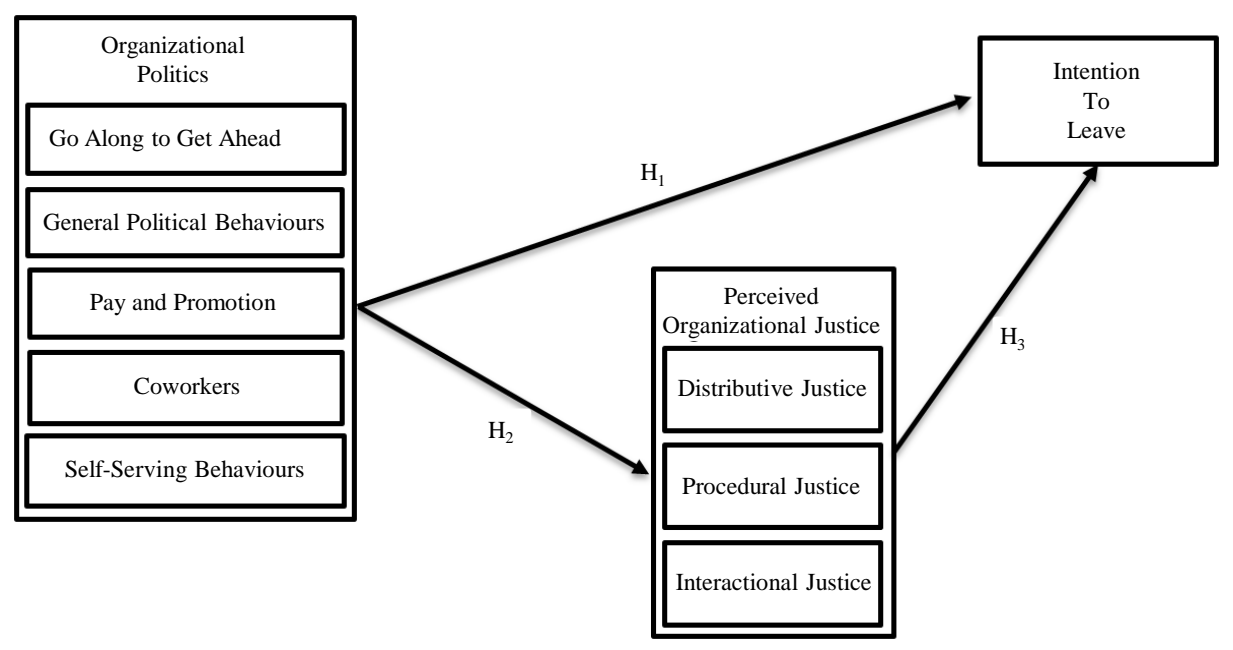

Figure 1. Research model. 
Table 1. Demographic characteristics of the sample.

\begin{tabular}{|c|c|c|c|}
\hline & & f & $\%$ \\
\hline \multirow{2}{*}{ Sector } & Public & 172 & 66.4 \\
\hline & Private & 87 & 33.6 \\
\hline \multirow{5}{*}{ Age } & $20-24$ & 20 & 7.7 \\
\hline & $25-29$ & 92 & 35.5 \\
\hline & $30-39$ & 91 & 35.1 \\
\hline & $40-49$ & 34 & 13.1 \\
\hline & $50-59$ & 22 & 8.5 \\
\hline \multirow{2}{*}{ Sex } & Male & 185 & 71.4 \\
\hline & Female & 74 & 28.6 \\
\hline \multirow{3}{*}{ Education } & High School & 15 & 5.8 \\
\hline & Bachelor's & 136 & 52.5 \\
\hline & Master's & 108 & 41.7 \\
\hline
\end{tabular}

\section{Findings}

Confirmatory factor analysis was conducted in order to explore the validity and the reliability of the scales. Overall, the scales were found to be valid and reliable. Fit indices for organizational politics scale $\left(\chi^{2} / \mathrm{df}=2.14<\right.$ 3 , RMSEA $=0.067<0.08, \mathrm{CFI}=0.90, \mathrm{GFI}=0.86$, AGFI $=0.82, \mathrm{NFI}=0.83)$ and perceived justice scale $\left(\chi^{2} / \mathrm{df}\right.$ $=1.87<3$, RMSEA $=0.058<0.08$, CFI $=0.96$, GFI $=0.89$, AGFI $=0.86$, NFI $=0.92$ ) were observed in the acceptable range.

As shown in Table 2, there was a significantly positive relationship between organizational politics and intention to leave $(r=0.310, p<0.01)$, while there was a significantly negative relationship between perceived organizational justice and intention to leave $(r=-0.351, p<0.01)$. Thus the hypotheses $\mathrm{H}_{1}$ and $\mathrm{H}_{3}$ were supported. In addition, there was a significantly negative relationship between organizational politics and perceived organizational justice $(\mathrm{r}=-0.581, \mathrm{p}<0.01)$. Thus the hypothesis $\mathrm{H}_{2}$ was supported.

In order to evaluate the relationship between the sub-dimensions of organizational politics and intention to leave, regression analysis was conducted. As shown in Table 3, three dimensions; "pay and promotion" ( $\beta=$ $-0.260, \mathrm{p}<0.01)$, "self-serving behaviours" $(\beta=-0.220, \mathrm{p}<0.01)$, and "coworkers" $(\beta=-0.184, \mathrm{p}<0.01)$ had significant effects on intention to leave. In contrast, other dimensions; "go along to get ahead" $(\beta=0.019, \mathrm{p}>$ $0.05)$ and "general political behaviours" ( $\beta=-0.044, p>0.05)$ had insignificant effects $\left(R^{2}=0.362\right)$.

The relationship between the sub-dimensions of perceived organizational justice and intention to leave was also evaluated through regression analysis. As shown in Table 4, only "distributive justice" had significant effect on intention to leave $\left(\beta=-0.301, \mathrm{p}<0.01, \mathrm{R}^{2}=0.138\right)$.

Finally, by conducting multi-regression analysis the sub-dimensions of organizational politics and their effects on distributive, procedural, and interactional justice were evaluated. As shown in Table 5, only "pay and promotion" had significant effect on distributive justice ( $B=-0.317, \mathrm{p}<0.01, \mathrm{R}^{2}=0.174$ ). On "procedural justice"; "pay and promotion" $(\beta=-0.140, \mathrm{p}<0.05)$, "self-serving behaviours" $(\beta=-0.280, \mathrm{p}<0.01)$ and "coworkers" ( $\beta=-0.197, \mathrm{p}<0.01)$ had significant effects $\left(\mathrm{R}^{2}=0.397\right)$. Similarly, "pay and promotion" $(\beta=$ -0.216, $\mathrm{p}<0.01)$, "self-serving behaviours" $(\beta=-0.184, \mathrm{p}<0.05)$ and "coworkers" $(\beta=-0.222, \mathrm{p}<0.01)$ had significant effects on "interactional justice" $\left(\mathrm{R}^{2}=0.297\right)$.

\section{Discussion}

The aim of this study was to explore the effects of employees' perceptions about organizational politics upon perceived organizational justice and intention to leave, as well as the relationship between these variables. As a result of the study, it was found out that perceptions about organizational politics has a significant correlation with perceived organizational justice $(r=0.581, \mathrm{p}<0.01)$. This result is in line with previous studies [10] [17]-[20]. Employees will feel that their working environment is unfair due to political struggles within the organization. These actions will definitely damage efforts to sustain justice that organizations are trying to establish 
Table 2. Correlation analysis.

\begin{tabular}{|c|c|c|c|c|c|c|c|c|c|c|c|c|c|}
\hline & M & SD & 1 & 2 & 3 & 4 & 5 & 6 & 7 & 8 & 9 & 10 & 11 \\
\hline 1 Distributive Justice & 3.00 & 0.85 & 1 & & & & & & & & & & \\
\hline 2 Procedural Justice & 2.84 & 0.93 & $0.557^{* *}$ & 1 & & & & & & & & & \\
\hline 3 Interactional Justice & 3.16 & 1.01 & $0.553^{* *}$ & $0.818^{* *}$ & 1 & & & & & & & & \\
\hline $4 \begin{array}{l}\text { Perceived Organizational } \\
\text { Justice }\end{array}$ & 3.02 & 0.84 & $0.736^{* *}$ & $0.913^{* *}$ & $0.950^{* *}$ & 1 & & & & & & & \\
\hline 5 Intention to Leave & 2.47 & 1.09 & $-0.340^{* *}$ & $-0.299^{* *}$ & $-0.309^{* *}$ & $-0.351^{* *}$ & 1 & & & & & & \\
\hline 6 Go Along to Get Ahead & 3.17 & 0.70 & $-0.227^{* *}$ & $-0.450^{* *}$ & $-0.352^{* *}$ & $-0.396^{* *}$ & $0.215^{* *}$ & 1 & & & & & \\
\hline 7 General Political Behaviours & 3.19 & 1.04 & $-0.293^{* *}$ & $-0.515^{* *}$ & $-0.411^{* *}$ & $-0.466^{* *}$ & $0.280^{* *}$ & $0.639^{* *}$ & 1 & & & & \\
\hline 8 Pay and Promotion & 2.94 & 0.76 & $-0.388^{* *}$ & $-0.472^{* *}$ & $-0.450^{* *}$ & $-0.497^{* *}$ & $0.292^{* *}$ & $0.501^{* *}$ & $0.527^{* *}$ & 1 & & & \\
\hline 9 Self-Serving Behaviours & 3.04 & 0.86 & $-0.336^{* *}$ & $-0.584^{* *}$ & $-0.475^{* *}$ & $-0.534^{* *}$ & $0.251^{* *}$ & $0.624^{* *}$ & $0.742^{* *}$ & $0.573^{* *}$ & 1 & & \\
\hline 10 Coworkers & 2.65 & 0.94 & $-0.313^{* *}$ & $-0.547^{* *}$ & $-0.480^{* *}$ & $-0.519^{* *}$ & $0.259^{* *}$ & $0.581^{* *}$ & $0.644^{* *}$ & $0.555^{* *}$ & $0.706^{* *}$ & 1 & \\
\hline 11 Organizational Politics & 3.09 & 0.65 & $-0.376^{* *}$ & $-0.616^{* *}$ & $-0.524^{* *}$ & $-0.581^{* *}$ & $0.310^{* *}$ & $0.825^{* *}$ & $0.812^{* *}$ & $0.781^{* *}$ & $0.860^{* * *}$ & $0.851^{* *}$ & 1 \\
\hline
\end{tabular}

**Correlation is significant at the 0.01 level (2-tailed).

Table 3. Regression analysis: organizational politics upon intention to leave.

\begin{tabular}{ccc}
\multicolumn{2}{c}{ Dependent Variable: Intention to Leave } & $\mathrm{p}$ \\
Independent Variable & $\beta$ & 0.822 \\
Go Along to Get Ahead & 0.019 & 0.506 \\
General Political Behaviours & -0.044 & 0.000 \\
Pay and Promotion & -0.260 & 0.010 \\
Self-Serving Behaviours & -0.220 & 0.008 \\
Coworkers & -0.184 & 0.601 \\
$\mathrm{R}$ & 0.362 & \\
\hline
\end{tabular}

Table 4. Regression analysis: perceived organizational justice upon intention to leave.

\begin{tabular}{ccc}
\hline \multicolumn{2}{c}{ Dependent Variable: Intention to Leave } & $\mathrm{p}$ \\
\hline Independent Variable & $\beta$ & 0.001 \\
Distributive Justice & -0.301 & 0.527 \\
Procedural Justice & -0.078 & 0.226 \\
Interactional Justice & -0.137 & \\
$\mathrm{R}$ & 0.372 & 0.138 \\
$\mathrm{R}^{2}$ & \\
\hline
\end{tabular}

Table 5. Regression analysis: organizational politics upon perceived organizational justice.

\begin{tabular}{|c|c|c|c|c|c|c|}
\hline \multirow{2}{*}{$\begin{array}{c}\text { Dependent Variable } \\
\text { Independent Variable }\end{array}$} & \multicolumn{2}{|c|}{ Distributive Justice } & \multicolumn{2}{|c|}{ Procedural Justice } & \multicolumn{2}{|c|}{ Interactional Justice } \\
\hline & $ß$ & $\mathrm{p}$ & $\beta$ & $\mathrm{p}$ & $\beta$ & $\mathrm{p}$ \\
\hline Go Along to Get Ahead & 0.081 & 0.402 & -0.036 & 0.594 & 0.020 & 0.785 \\
\hline General Political Behaviours & -0.032 & 0.669 & -0.083 & 0.291 & -0.031 & 0.720 \\
\hline Pay and Promotion & -0.317 & 0.000 & -0.140 & 0.026 & -0.216 & 0.002 \\
\hline Self-Serving Behaviours & -0.132 & 0.177 & -0.280 & 0.001 & -0.184 & 0.043 \\
\hline Coworkers & -0.070 & 0.379 & -0.197 & 0.008 & -0.222 & 0.006 \\
\hline $\mathrm{R}$ & 0.418 & & 0.630 & & 0.545 & \\
\hline $\mathrm{R}^{2}$ & 0.174 & & 0.397 & & 0.297 & \\
\hline
\end{tabular}


with defining rules and regulations. As [20] suggested, political perceptions of employees should be taken into account because their individual perceptions about justice is related to those.

The results of the analysis indicated that organizational politics also have positive effects on employee's intention to leave $(r=0.310, p<0.01)$. Scholars like [10] [12] [21] [45] [50] have mentioned this fact similarly. In general, employees want to work in an environment where political behaviours are not experienced. Many of them choose not to take place in such activities and also get worried about their future in the organization.

Another finding was that a negative relationship existed between organizational justice and intention to leave $(\mathrm{r}=-0.581, \mathrm{p}<0.01)$. This relation was also mentioned by [10] [11] [15] and [16]. Employees will feel safer and comfortable in a fair environment. They will have less concern about their expectations from the organization. It may also be expected that perceptions of justice will affect their work outcomes positively.

Supervisors who prevent political behaviours are important if employees are to feel that justice exists. This is because employees highly perceive justice and are encouraged to develop positive behaviours when they do not consider their organization as political. Moreover, their intention to leave is decreased and so does overall turnover. Conversely, organizations either lose employees or demotivate them, which in turn decreases efficiency and productivity. It is clear that, if justice is embedded, employees' intention to leave will decrease. To this extent, then, managers should focus on creating a workplace where justice exists, so that employees are able to concentrate on giving the maximum to their organizations.

One limitation of this study was that the effects of culture were not taken into account. If a similar study is conducted on various workplace cultures, then it would improve how the roles found in organizational politics are understood in relation to other constructs. Another limitation related to the fact that participants in this study included employees who work in public institutions. These people choose to work in such institutions because of job security. Further studies, therefore, should focus on the private sector, as well as different types of employees, such as blue- or white-collar.

\section{References}

[1] Allen, R.W., Madison D.L., Porter, L.W., Renwick, P.A. and Mayes, B.T. (1979) Organizational Politics: Tactics and Characteristics of Its Actors. California Management Review, 22, 77-83. http://dx.doi.org/10.2307/41164852

[2] Gull, S. and Zaidi, A.A. (2012) Impact of Organizational Politics on Employees' Job Satisfaction in the Health Sector of Lahore Pakistan. Interdisciplinary Journal of Contemporary Research in Business, 4, 156-170.

[3] Zaleznik, A. (1999) Power and Politics in Organizational Life. The McKinsey Quarterly, 7, 52-69.

[4] Ferris, G.R., Russ, G.S. and Fandt, P.M. (1989) Politics in Organizations. In: Giacalone, R.A. and Rosenfeld, P., Eds., Impression Management in the Organization, Erlbaum, Hillsdale, NJ, 143-170.

[5] Drory, A. (1993) Perceived Political Climate and Job Attitudes. Organization Studies, 14, 59-71. http://dx.doi.org/10.1177/017084069301400105

[6] Utami, A.F., Bangun, R.Y. and Lantu, D.C. (2014) Understanding the Role of Emotional Intelligence and Trust to the Relationship between Organizational Politics and Organizational Commitment. Social and Behavioural Sciences, 115, 378-386. http://dx.doi.org/10.1016/j.sbspro.2014.02.444

[7] Vigoda, E. (2000) Organizational Politics, Job Attitudes, and Work Outcomes: Exploration and Implications for the Public Sector. Journal of Vocational Behaviour, 57, 326-347. http://dx.doi.org/10.1006/jvbe.1999.1742

[8] Harris, R.B., Harris, K.J. and Harvey, P. (2007) A Test of Competing Models of the Relationships among Perceptions of Organizational Politics, Perceived Organizational Support, and Individual Outcomes. The Journal of Social Psychology, 147, 631-656. http://dx.doi.org/10.3200/SOCP.147.6.631-656

[9] Kim, J.-K. and Fu, Y. (2015) The Effect of Perceptions of Organizational Politics on Turnover Intention and Organizational Citizenship Behaviour in Chinese Convergency Companies. Journal of Digital Convergence, 13, 177-189.

[10] Cropanzano, R., Howes, J.C., Grandey, A.A. and Toth, P. (1997) The Relationship of Organizational Politics and Support to Work Behaviours, Attitudes, and Stress. Journal of Organizational Behaviour, 18, 159-180. http://dx.doi.org/10.1002/(SICI)1099-1379(199703)18:2<159::AID-JOB795>3.0.CO;2-D

[11] Hochwarter, W.A., Perrewé, P.L., Ferris, G.R. and Guercio, R. (1999) Commitment as an Antidote to the Tension and Turnover Consequences of Organizational Politics. Journal of Vocational Behaviour, 55, 277-297. http://dx.doi.org/10.1006/jvbe.1999.1684

[12] Kacmar, K.M. and Baron, R.A. (1999) Organizational Politics: The State of the Field, Links to Related Processes, and an Agenda for Future Research. In: Ferris, G.R., Ed., Research in Personnel and Human Resources Management, JAI Press, Greenwich, CT, 1-39 . 
[13] Buchanan, D.A. (2008) You Stab My Back, I'll Stab Yours: Management Experience and Perception of Organization Political Behaviour. British Journal of Management, 19, 49-64. http://dx.doi.org/10.1111/j.1467-8551.2007.00533.x

[14] Vigoda-Gadot, E. and Talmud, I. (2010) Organizational Politics and Job Outcomes: The Moderating Effects of Trust and Social Support. Journal of Applied Social Psychology, 40, 2829-2861. http://dx.doi.org/10.1111/j.1559-1816.2010.00683.x

[15] Parker, R.J. and Kohlmeyer, J.M. (2005) Organizational Justice and Turnover in Public Accounting Firms: A Research Note. Accounting, Organizations and Society, 30, 357-369. http://dx.doi.org/10.1016/j.aos.2004.05.001

[16] Zagladi, A.N., Hadiwidjojo, D., Rahayu, M. and Noermijati. (2015) The Role of Job Satisfaction and Power Distance in Determining the Influence of Organizational Justice toward the Turnover Intention. Social and Behavioural Sciences, 211, 42-48. http://dx.doi.org/10.1016/j.sbspro.2015.11.007

[17] Byrne, Z.S. (2005) Fairness Reduce the Negative Effects of Organizational Politics on Turnover Intentions, Citizenship Behavior and Job Performance. Journal of Business and Psychology, 20, 175-200. http://dx.doi.org/10.1007/s10869-005-8258-0

[18] Andrews, M.C. and Kacmar, K.M. (2001) Discriminating among Organizational Politics, Justice and Support. Journal of Organizational Behaviour, 22, 347-366. http://dx.doi.org/10.1002/job.92

[19] Rosen, C.C. and Hochwarter, W.A. (2014) Looking Back and Falling Further Behind: The Moderating Role of Rumination on the Relationship between Organizational Politics and Employee Attitudes, Well-being, and Performance. Organizational Behaviour and Human Decision Processes, 124, 177-189. http://dx.doi.org/10.1016/j.obhdp.2014.03.003

[20] Harris, K.J., Andrews, M.C. and Kacmar, M.K. (2007) The Moderating Effects of Justice on the Relationship between Organizational Politics and Workplace Attitude. Journal of Business Psychology, 22, 135-144. http://dx.doi.org/10.1007/s10869-007-9054-9

[21] Ferris, G.R. and Kacmar, K.M. (1992) Perception of Organizational Politics. Journal of Management, 18, 93-116. http://dx.doi.org/10.1177/014920639201800107

[22] Al-Tuhaih, S.M. and Van Fleet, D.D. (2011) An Exploratory Study of Organizational Politics in Kuwait. Thunderbird International Business Review, 53, 93-104. http://dx.doi.org/10.1002/tie.20392

[23] Mayes, B.T. and Allen, R.W. (1977) Toward a Definition of Organizational Politics. Academy of Management Review, 2, 672-678.

[24] Cropanzano, R.S., Kacmar, K.M. and Bozeman, D.P. (1995) Organizational Politics, Justice, and Support: Their Differences and Similarities. In: Cropanzano, R.S. and Kacmar, K.M., Eds., Organizational Politics, Justice, and Support: Managing Social Climate at Work, Quorum Books, Westport, I-IX.

[25] Kacmar, K.M. and Carlson, D.S. (1997) Further Validation of the Perceptions of Politics Scale (POPS): A Multiple Sample Investigation. Journal of Management, 23, 627-658. http://dx.doi.org/10.1177/014920639702300502

[26] Mintzberg, H. (1985) The Organization as Political Arena. The Journal of Management Studies, 22, 133-154. http://dx.doi.org/10.1111/j.1467-6486.1985.tb00069.x

[27] Bodla, M. and Danish, R.Q. (2009) Politics and Workplace: An Empirical Examination of the Relationship between Perceived Organizational Politics and Work Performance. South Asian Journal of Management, 16, 44-62.

[28] Drory, A. and Romm, T. (1989) Politics in Organization and Its Perception within the Organization. Organization Studies, 9, 165-179. http://dx.doi.org/10.1177/017084068800900202

[29] Ferris, G.R. and King, T.R. (1991) Politics in Human Resources Decisions: A Walk on the Dark Side. Organizational Dynamics, 20, 59-71. http://dx.doi.org/10.1016/0090-2616(91)90072-H

[30] Gandz, J. and Murray, V.V. (1980) The Experience of Workplace Politics. Academy of Management Journal, 23, 237-251. http://dx.doi.org/10.2307/255429

[31] Madison, D.L., Allen, R.W., Porter, L.W., Renwick, P.A. and Mayes, B.T. (1980) Organizational Politics: An Exploration of Managers' Perception. Human Relations, 33, 79-100. http://dx.doi.org/10.1177/001872678003300201

[32] Eisenhardt, K. and Bourgeois, L.J. (1988) Politics of Strategic Decision Making in High-Velocity Environments: Toward a Midrange Theory. Academy of Management Journal, 31, 737-770. http://dx.doi.org/10.2307/256337

[33] Yen, W.W., Chen, S.C. and Yen, S.I. (2009) The Impact of Perceptions of Organizational Politics on Workplace Friendship. African Journal of Business Management, 3, 548-554.

[34] Perrewe, P.L., Ferris, G.R., Frink, D.D. and Anthony, W.P. (2000) Political Skill: An Antidote for Workplace Stressors. The Academy of Management Executive, 14, 115-123. http://dx.doi.org/10.5465/ame.2000.4468071

[35] Ferris, G.R., Fedor, D.B., Chachere, J.G. and Pondy, L.R. (1989) Myths and Politics in Organizational Contexts. Group and Organization Studies, 14, 83-103. http://dx.doi.org/10.1177/105960118901400108 
[36] Parker, C.P., Dipboye, R.L. and Jackson, S.L. (1995) Perceptions of Organizational Politics: An Investigation of Antecedents and Consequences. Journal of Management, 21, 891-912. http://dx.doi.org/10.1177/014920639502100505

[37] Kacmar, K.M., Bozeman, D.P., Carlson, D.S. and Anthony, W.P. (1999) An Examination of the Perceptions of Organizational Politics Model: Replication and Extension. Human Relations, 52, 383-416. http://dx.doi.org/10.1177/001872679905200305

[38] Homans, G.C. (1961) Social Behavior: Its Elementary Forms. Harcourt, Brace, and World, New York.

[39] Adams, J.S. (1965) Inequity in Social Exchange. In: Berkovitz, L., Ed., Advances in Experimental Social Psychology, Academic Press, New York, 267-299. http://dx.doi.org/10.1016/S0065-2601(08)60108-2

[40] Walster, E., Berscheid, E. and Walster, G.W. (1973) New Directions in Equity Research. Journal of Personality and Social Psychology, 25, 151-176. http://dx.doi.org/10.1037/h0033967

[41] Greenberg, J. (1987) A Taxonomy of Organizational Justice Theories. The Academy of Management Review, 12, 9-22.

[42] Colquitt, J.A. (2001) On the Dimensionality of Organizational Justice: A Construct Validation of a Measure. Journal of Applied Psychology, 86, 386-400. http://dx.doi.org/10.1037/0021-9010.86.3.386

[43] Luo, Y. (2007) The Independent and Interactive Roles of Procedural, Distributive, and Interactional Justice in Strategic Alliances. Academy of Management Journal, 50, 644-664. http://dx.doi.org/10.5465/AMJ.2007.25526452

[44] Niehoff, B.P. and Moormon, R.H. (1993) Justice as a Mediator of the Relationship between Methods of Monitoring and Organizational Citizenship Behavior. Academy of Management Journal, 36, 527-556. http://dx.doi.org/10.2307/256591

[45] Ram, P. and Prabhakar, G.V. (2010) Leadership Styles and Perceived Organizational Politics as Predictors of Work Related Outcomes. European Journal of Social Sciences, 15, 40-55.

[46] Mobley, W.H., Griffeth, R.W., Hand, H.H. and Meglino, B.M. (1979) Review and Conceptual Analysis of the Employee Turnover Process. Psychological Bulletin, 86, 493-522. http://dx.doi.org/10.1037/0033-2909.86.3.493

[47] Kassing, J.W., Piemonte, N.M., Goman, C.C. and Mitchell, C.A. (2012) Dissent Expression as an Indicator of Work Engagement and Intention to Leave. Journal of Business Communication, 49, 237-253. http://dx.doi.org/10.1177/0021943612446751

[48] Tett, R.P. and Meyer, J.P. (1993) Job Satisfaction, Organizational Commitment, Turnover Intention, and Turnover: Path Analyses Based on Meta-Analytic Findings. Personnel Psychology, 46, 259-293. http://dx.doi.org/10.1111/j.1744-6570.1993.tb00874.x

[49] Milgrom, P. and Oster, S. (1987) Job Discrimination, Market Forces and the Invisibility Hypothesis. Quarterly Journal of Economics, 102, 453-476. http://dx.doi.org/10.2307/1884213

[50] Harris, J.K., James, M. and Boonthanom, R. (2005) Perception of Organizational Politics and Cooperation as Moderators of the Relationship between Job Strains and Intent to Turnover. Journal of Managerial Issues, 17, $26-42$.

[51] Cohen-Charash, Y. and Spector, P.E. (2001) The Role of Justice in Organizations: A Meta-Analysis. Organizational Behavior and Human Decision Processes, 86, 278-321. http://dx.doi.org/10.1006/obhd.2001.2958

[52] Netemeyer, R.G., James, S.B., McKee, D.O. and Robert, M.M. (1997). An Investigation into the Antecedents of Organizational Citizenship Behaviors in a Personal Selling Context. Journal of Marketing, 61, 85-98. http://dx.doi.org/10.2307/1251791 